\title{
PENGEMBANGAN BERPIKIR KRITIS DALAM PEMBELAJARAN PENDIDIKAN KEWARGANEGARAAN MENGGUNAKAN PROJECT CITIZEN
}

\author{
Yosaphat Haris Nusarastriya, H. Sapriya, H. Abdul Azis Wahab, dan H. Dasim Budimansyah \\ Sekolah Pascasarjana Universitas Pendidikan Bandung
}

\begin{abstract}
Abstrak: Penelitian ini dilatarbelakangi oleh kebutuhan untuk mengembangkan kemampuan berpikir kritis dengan pembelajaran yang lebih inovatif yaitu menggunakan project citizen. Penelitian ini dilaksanakan di Universitas Kristen Satya Wacana Salatiga dengan subjek penelitian mahasiswa. Data diambil melalui studi dokumentasi, angket, tes, observasi, dan wawancara. Pengolahan data dilakukan dengan statistik dan didukung teori-teori tentang berpikir kritis seperti teori mengenai sikap positif untuk berpikir kritis dari John Langrehr (2006), kemampuan berpikir kritis dari CCEI (2004), karakter berpikir kritis dari Moore and Parker (2009) dan teori-teori yang berkaitan dengan project citizen seperti teori mengenai research-oriented learning dan inquiry learning. Penelitian dilakukan dengan metode quasi eksperimen untuk uji beda antara kelas yang menggunakan project citizen dan kelas konvensional. Untuk pengembangan digunakan desain eksperimental dengan menambah pemahaman mengenai berpikir kritis. Hasil penelitian menunjukkan bahwa pengembangan berpikir kritis menggunakan project citizen yang didahului dengan pemahaman tentang berpikir kritis akan lebih maksimal.
\end{abstract}

Kata Kunci: project citizen, berpikir kritis, pendidikan kewarganegaraan

\section{DEVELOPING CRITICAL THINKING IN CIVIC EDUCATION TEACHING USING THE PROJECT CITIZEN}

\begin{abstract}
The background of the study was that it was necessary to develop critical thinking by using innovative teaching, that is, project citizen. This study was carried out in Satya Wacana Christian University Salatiga with the subjects of students. The data were collected using documentation, questionnaires, a test, and interview and analyzed using statistics supported by theories about critical thinking such as theories on positive attitude for critical thinking by John Langrehr (2006), critical thinking ability by CCEI (2004), characteristics of critical thinking by Moore and Parker (2009) and other theories related to project citizen like theories on research-oriented learning and inquiry learning. The study was carried out using the quasi-experimental method to find the difference between the class taught using the project citizen and that taught using the conventional method. The experimental design was used in the development to improve the understanding of the critical thinking. The findings showed that the development of the critical thinking using project citizen initialized by understanding of critical thinking could be maximized.
\end{abstract}

Keywords: project citizen, critical thinking, civic education

\section{PENDAHULUAN}

Ada tiga hal serius yang menjadi latar belakang penelitian ini, pertama yaitu masalah dan tuntutan tentang perlunya investasi besar dalam bidang intelektual manusia menghadapi kompleksitas permasalahan yang ada di abad 21 ini. Naisbit (1990:19) pernah menyatakan bahwa dewasa ini banyak terjadi paradoks (di mana hal itu juga dapat terjadi pada pemikiran) sehingga muncul hal-hal yang kontroversial termasuk isu-isu sebagai konsekuensi dari kekompleksitasan masalah. Oleh karena itu, critical thinking and problem solving menjadi unsur penting jika manusia ingin bertahan hidup di abad ke-21 ini.

Kedua, keprihatinan terhadap kondisi sosial yang melibatkan dunia persekolahan seperti tawuran pelajar dan mahasiswa. Mungkinkah hal itu merupakan indikator berkembangnya radikalisme di masyarakat atau 
dunia persekolahan? Menurut data hasil penelitian indeks kerentanan radikalisme di Indonesia pada tahun 2011 yang dirilis oleh Birru (2011) di Media Center pada 15 Oktober adalah 43,6 . Indeks radikalisme ini diperoleh dari hasil penelitian kerentanan radikalisme terhadap 33 provinsi dengan jumlah responden sebanyak 4840. Berpikir kritis sebagai unsur karakter bangsa yang cerdas harus dikembangkan di dunia persekolahan sampai Perguruan Tinggi.

Ketiga, tuntutan yang lebih inovatif dalam proses pembelajaran dan harapan agar pengembangan berpikir kritis diperhatikan dalam proses pembelajaran dan dalam bidang studi atau mata kuliah. Kritikan tajam dalam kaitannya dengan ini dilakukan oleh Pitalokasari (2012) yang menyoroti proses pembelajaran kaitannya dengan kualitas lulusan perguruan tinggi. Menurutnya, jika dosen masih menggunakan metode mengajar konvensional, kurikulum sebagus apa pun tidak bisa membentuk lulusan yang berkualitas.

Keprihatinan dalam kaitannya dengan pengembangan berpikir kritis dikemukakan antara lain oleh Sanusi (1998:222-227) yang melihat dominannya latihan berpikir taraf rendah khususnya dalam pembahasannya mengenai perspektif Pendidikan Ilmu Pengetahuan Sosial. Keprihatinan yang lain dikemukakan oleh Wahab (2008:48) yang mengatakan bahwa guru terkadang hanya menggunakan cara berpikir konvergen sedang berpikir divergen sangat kurang, padahal berpikir seperti ini sangat penting bagi siswa. Di pihak lain, Sapriya (2008) menangkap ada kecenderungan bahwa belum banyak muncul kesadaran yang tinggi di kalangan pendidik di persekolahan untuk mengajar para siswa tentang kondisi dunia yang semakin berkembang pesat yang menuntut adanya respon dengan pemikiran kritis.

Beberapa kajian teori yang dapat dikemukakan antara lain dari Langrehr (2006) yaitu mengenai sikap positif untuk berpikir kritis sebagai salah satu elemen yang menjadi prasyarat agar dapat berpikir kritis dengan baik. Elemen ini terdiri dari kemampuan melakukan klarifikasi, kemampuan bersikap terbuka, kemampuan berpikir objektif dan kemampuan berpikir fleksibel. Teori yang selanjutnya dari CCE (2004) yaitu kemampuan berpikir kritis. Kemampuan berpikir kritis merupakan salah satu elemen berpikir kritis yang unsurnya meliputi melakukan identifikasi, menggambarkan dan menjelaskan, melakukan evaluasi, tuntutan kemampuan berpendapat, kemampuan mempertahankan pendapat dan kemampuan mendengar (CCE, 2004).

Moore \& Parker (2009) mengemukakan bahwa mengenai karakteristik berpikir kritis merupakan salah satu elemen yang memberi ciri bahwa berpikir yang dimaksud adalah berpikir kritis. Elemen ini terdiri dari menentukan informasi yang tepat, membedakan klaim yang rasional dan emosional, memisahkan antara fakta dan pendapat, menentukan bukti apakah terbatas atau bisa diterima, menunjukkan tipuan dan kekurangan dalam argumentasi orang lain, menunjukkan analisis data atau informasi, menyadari kesalahan logika, menggambarkan hubungan antara sumber-sumber data yang terpisah, memperhatikan informasi yang bertentangan tidak memadai, membangun argumen yang meyakinkan yang berakar pada data, memilih data penunjang yang paling kuat, menghindarkan kesimpulan yang berlebihan, mengidentifikasi celah-celah dalam bukti dan menyarankan pengumpulan informasi tambahan, menyadari tidak jelas atau banyaknya kemungkinan jawaban suatu masalah, mengusulkan opsi lain dalam pengambilan keputusan, mempertimbangkan semua pemangku kepentingan atau, menyatakan argumen dan konteks untuk apa argumen itu, menggunakan bukti secara betul dan tepat untuk menyanggah argumen, menyusun argumen secara logis dan kohesif, menunjukkan bukti untuk mendukung argumen yang meyakinkan.

Suabuana (2010) lewat penelitiannya tentang Pengembangan Pendidikan Nilai Bela Negara Dalam Pendidikan Kewarganegaraan Pada Perguruan Tinggi Melalui Model Pembelajaran Project Citizen" menemukan bahwa secara umum kelas yang menggunakan project citizen lebih baik dibandingkan kelas yang diselenggarakan secara konvensional. Menurut hasil analisis penelitian dapat disimpulkan 
bahwa pada indikator model pembelajaran kelompok kontrol diperoleh nilai rata-rata sebesar 64,12, sedangkan untuk kelompok eksperimen 114,55. Hal tersebut mengindikasikan bahwa pada kelompok eksperimen atau project citizen lebih baik dibandingkan dengan model konvensional. Walaupun penelitian tersebut tidak secara khusus tentang pengembangan berpikir kritis melainkan mengenai bela negara.

Penelitian Maksum (2011) tentang "Model Project Citizen Untuk Meningkatkan Kecakapan Pendidikan Kewarganegaraan Pada Konsep Pengembangan Sikap Nasionalisme" memperlihatkan kesamaan hasil bahkan saling memperkuat khususnya pada unsur kecakapan intelektual (intelectual skills). Disimpulkan dalam penelitian itu bahwa Project citizen meningkatkan kecakapan kewarganegaraan berpengaruh signifikan khususnya pada indikator mengidentifikasi masalah tetapi tidak berpengaruh signifikan terhadap kecakapan partisipatoris (partisipatory skills) dengan diperolehnya nilai $p$-value sebesar 0,064 sehingga nilai $\mathrm{p}$ - value $>0,05$ dan hanya berpengaruh sedang terhadap kecakapan kewarganegaraan dengan diperolehnya nilai $\mathrm{p}$-value sebesar 0,503 sehingga nilai $\mathrm{p}$-value $>0,05$.

Dari penelitian lintas negara yang dilaporkan oleh International Democratic Education Institute (Craddock, 2007) mengambil kesimpulan bahwa project citizen memberikan dampak bagi pengetahuan, sikap dan keterampilan kewarganegaraan siswa. Meskipun demikian, ruang lingkup (jangkauan) dan derajat pengaruh ini sangat beragam di antara berbagai kawasan di beberapa Negara. Dalam hal ini Craddock (2007) mengemukakan: "We emerge from this long, complex and multi-national research convinced that Project Citizen impacts student civic knowledge, attitudes and skills. However, the scope and degree of this impact varies greatly among different sites in the study with some countries showing little statistical evidence of impact while others show a great deal".

Project citizen yang dimaksud disini yaitu model pembelajaran berbasis portofolio yang dikembangkan atas dasar pendekatan reflective inquiry yang secara generik memiliki langkah-langkah sebagai berikut. (1) mengidentifikasi masalah kebijakan publik yang ada dalam masyarakat; (2) pemilihan masalah sebagai fokus kajian kelas; (3) pengumpulan informasi terkait masalah yang menjadi fokus kajian kelas; (4) pengembangan suatu portofolio kelas; (5) penyajian portofolio (show case); (6) kajian pengendapan atas pengalaman belajar yang dilakukan.

\section{METODE}

Penelitian ini menggunakan eksperimen dengan subjek penelitian adalah mahasiswa UKSW Salatiga, Jawa Tengah. Pengumpulan data dilakukan dengan tehnik dokumentasi, observasi, angket, dan tes serta wawancara. Penelitian ini diawali dengan studi pustaka dan lapangan serta wawancara mengenai pembelajaran Pendidikan Kewarganegaraan serta dengan angket untuk melihat bagaimana pemahaman mengenai berpikir kritis mahasiswa yang meliputi tiga aspek yaitu sikap positif dalam berpikir kritis, kemampuan berpikir kritis dan karakteristik berpikir kritis. Setelah itu, dilakukan uji coba tahap pertama menggunakan quasi eksperimen dengan kelas kontrol dan kelas inovatif (eksperimen) dan selanjutnya uji coba kedua dilakukan pengembangan menggunakan dexsperimental desain (desain beforeafter) menggunakan project citizen tetapi menambah pemahaman mengenai berpikir kritis itu sendiri melalui desain pembelajaran berpikir kritis.

\section{HASIL DAN PEMBAHASAN \\ Hasil}

Berdasarkan hasil uji $\mathrm{t}$ untuk menguji hipotesis tentang perbedaan sikap positif, kemampuan dan karakteristik berpikir kritis antara kelas kontrol dan kelas eksperimen adalah sebagai berikut.

Mengenai sikap positif untuk berpikir kritis diperoleh mean untuk kelas eksperimen sebesar 15.348 dan kelas kontrol sebesar 13.09. dari uji beda didapat nilai $\mathrm{t}$ sebesar 10.448 dengan signifikansi sebesar 0.000. Dikarenakan tingkat signifikansi jauh dibawah 0.005 ( $\mathrm{p}<$ 
0.005) maka dapat dikatakan terdapat perbedaan antara kelas eksperimen dan kelas kontrol. Perbedaan tersebut sebesar 2.256 (17.23\%). Dengan demikian terjadi perbedaan pada sikap positif antara kelas eksperimen dan kelas kontrol sebesar $17.23 \%$.

Selanjutnya, untuk kemampuan berpikir kritis data menunjukkan mean untuk kelas eksperimen sebesar 17.884 dan kelas kontrol sebesar 15.209. Dari uji beda didapat nilai $t$ sebesar 12.442 dengan signifikansi sebesar 0.000. Dikarenakan tingkat signifikansi jauh dibawah 0.005 ( $\mathrm{p}<0.005)$ maka dapat dikatakan terdapat perbedaan antara kelas eksperimen dan kelas kontrol. Perbedaan tersebut sebesar 2.674 (17.58\%). Dengan demikian, terjadi perbedaan pada kemampuan antara kelas eksperimen dan kelas kontrol sebesar $17.58 \%$. Mengenai karakteristik berpikir kritis diperoleh perbedaan sangat signifikan antara kelas eksperimen dan kelas kontrol sebagaimana hasilnya dapat dilihat di bawah.

Mean untuk kelas eksperimen sebesar 62.511 dan kelas kontrol sebesar 49.93. dari uji beda didapat nilai $t$ sebesar 15.916 dengan signifikansi sebesar 0.000. Dikarenakan tingkat signifikansi jauh dibawah $0.005(\mathrm{p}<0.005)$ maka dapat dikatakan terdapat perbedaan antara kelas eksperimen dan kelas kontrol. Perbedaan tersebut sebesar 12.581 (25.20\%). Dengan demikian, terjadi perbedaan pada karakteristik antara kelas eksperimen dan kelas kontrol sebesar $25.20 \%$.

Berdasarkan hasil uji coba di atas kelas yang menggunakan project citizen lebih baik, namun masih belum maksimal. Oleh karena itu, dilakukan uji coba yang kedua dengan memberi pemahaman berpikir kritis terlebih dahulu karena berdasarkan hasil angket pemahaman menunjukkan belum mencapai kategori yang ideal. Pada uji coba yang kedua ini juga ditambah desain pembelajaran untuk mengembangkan berpikir kritis dengan tetap menggunakan project citizen.

Berdasarkan hasil penelitian tahap kedua yang didahului dengan pemahaman mengenai berpikir kritis dibandingkan dengan tahap pertama yang tidak didahului dengan pemahaman berpikir kritis walaupun sama-sama menggunakan Project citizen menunjukkan adanya peningkatan hasil. Untuk elemen sikap positip dalam berpikir kritis ada perbedaan sebesar $15.99 \%$. Selanjutnya untuk elemen kemampuan berpikir kritis ada perbedaan sebesar 46,74\%. Pada elemen karaktristik berpikir kritis ada peningkatan walaupun tidak sebesar dua komponen lain yaitu sebesar $16.36 \%$. Artinya untuk kemampuan berpikir kritis berpengaruh signifikan, sedang untuk aspek sikap positif dan karakteristik berpengaruh berpengaruh sedang.

\section{Pembahasan}

Hasil penelitian ini jika dibandingkan dengan hasil penelitian Maksum (2011) yang sama-sama menggunakan project citizen memperlihatkan kesamaan hasil bahkan saling memperkuat khususnya pada unsur kecakapan intelektual (intelectual skills). Disimpulkan dalam penelitian itu bahwa project citizen meningkatkan kecakapan kewarganegaraan berpengaruh signifikan khususnya pada indikator mengidentifikasi masalah tetapi tidak berpengaruh signifikan terhadap kecakapan partisipatoris (partisipatory skills) dengan diperolehnya nilai $p$-value sebesar 0,064 sehingga nilai $\mathrm{p}$ - value $>0,05$ dan hanya berpengaruh sedang terhadap kecakapan kewarganegaraan dengan diperolehnya nilai $\mathrm{p}$-value sebesar 0,503 sehingga nilai $\mathrm{p}$-value $>0,05$.

Begitu juga jika dibanding dengan hasil penelitian Suabuana (2010) yang juga tentang project citizen" menunjukkan kesamaan secara umum bahwa kelas yang menggunakan project citizen lebih baik dibandingkan kelas yang diselenggarakan secara konvensional. Menurut hasil analisis penelitian dapat disimpulkan bahwa rata-rata model pada kelompok konvensional lebih rendah dari kelompok yang menggunakan project citizen walaupun penelitian tersebut tidak secara khusus tentang pengembangan berpikir kritis.

Dari penelitian lintas negara yang dilaporkan oleh International Democratic Education Institute (Craddock dkk, 2007) mengambil kesimpulan bahwa project citizen memberikan dampak/pengaruh bagi pengetahuan, sikap dan 
keterampilan kewarganegaraan siswa. Meskipun demikian, ruang lingkup (jangkauan) dan derajat pengaruh ini sangat beragam di antara berbagai kawasan di beberapa Negara. Apa yang menjadi alasan dari pernyataannya? Karena Project citizen memiliki rancangan yang bersifat generic dan secara mudah dapat diadaptasi dalam praktik. Because Project Citizen is generic by design and so readily adapted in practice, discerning the direct impac of the curriculum on student civic knowledge, attitudes and skills has proved to be very challenging task. (Craddock dkk, 2007).

Apa yang terjadi dalam proses belajar mahasiswa melalui Project citizen menunjukkan kesamaan unsur dengan pendekatan yang dimaksud oleh Fromm (1987:23) mengenai modus "menjadi" yang dimaksudkan karena mahasiswa tidak sekedar menerima pengetahuan tetapi juga memproses, menemukan melalui diskusi merumuskan masalah, melakukan kajian dan juga melakukan penelitian serta membuat usulan kebijakan. Hal itu juga sesuai dengan yang dikemukakan Muhadjir (2002:22) mengenai fungsi pendidikan menurut preparation theory yaitu mengembangkan kemampuan produktif karena mahasiswa melalui Project citizen mengalami suatu proses interaksi mengembangkan gagasan-gagasan baru untuk membuat usulan alternatif dan rencana tindakan.

Hasil uji coba kedua (tahap kedua) mengukuhkan pandangan Liliasari (2010) Wahab (2008) Sumardjono (2001) yang mengatakan bahwa berpikir kritis berkaitan dengan aspek kognitif (penguasaan serta pemahaman materi). Penguasaan dan pemahaman materi salah satunya dipengaruhi oleh faktor metode atau model pembelajaran yang memang dapat mendorong dan membantu mahasiswa mempermudah menangkap materi atau informasi. Proses pembelajaran yang semacam itu bagi mahasiswa ikut menentukan kemampuan berpikir kritis.

\section{Temuan Penelitian}

Ditinjau dari tiga elemen berpikir kritis (sikap positif, kemampuan, dan karakteristik berpikir kritis) maka project citizen lebih tepat dan baik untuk mengembangkan karakteristik berpikir kritis. Project citizen bukan model untuk mengembangkan pemikiran yang berciri spekulatif metafisis. Melainkan mengembangkan pemikiran yang bersifat eksistensial-positif dan operasional pragmatik yang menopang cara kerja ilmiah (ilmu pengetahuan) karena mengandalkan argumen, data objektif yang bersifat empiris, dan terukur. Pemahaman mengenai berpikir kritis mempunyai arti penting dalam rangka proses pengembangan berpikir kritis. Penelitian ini telah membuktikan bahwa Project citizen tanpa pemahaman mengenai berpikir kritis memperlihatkan hasil kurang maksimal pada dua elemen yaitu elemen sikap positif dan elemen kemampuan berpikir kritis. Temuan penelitian ini memperkuat konsep belajar mengajar dengan pengertian atau pemahaman bukan sekedar dengan hafalan saja.

\section{PENUTUP}

Secara umum, dalam kaitannya dengan pengembangan berpikir kritis, menggunakan project citizen lebih membawa hasil yang baik dibandingkan dengan pembelajaran konvensional karena sangat erat dengan unsur democratic teaching dan cooperative teaching yang ada di dalam project citizen yang memberi suasana terbuka dan partisipatif. Secara khusus dalam hal mengembangkan karakteristik berpikir kritis, project citizen lebih meningkatkan karakteristik khususnya dalam menghadapi, memanfaatkan informasi, membedakan klaim yang rasional dan emosional, kemampuan menunjukkan analisis data, kemampuan berargumentasi, kemampuan menggunakan bukti.

Pengembangan berpikir kritis dalam PKn menggunakan project citizen lebih baik didahului dengan memberikan pemahaman mengenai elemen-elemen berpikir kritis dan berpikir pada umumnya, berpikir ilmiah, tingkattingkat berpikir serta model berpikir karena terbukti dalam tahap kedua dengan desain pembelajaran yang mengembangkan berpikir kritis hasilnya lebih maksimal. 


\section{Rekomendasi}

Project citizen perlu diagendakan dalam proses pembelajaran mengingat kelebihan model ini untuk mengembangkan berpikir kritis dan mencapai kompetensi yang diharapkan. Khususnya dalam hubungannya dengan membangun karakter berpikir kritis di dunia akademik dan persekolahan. Dalam mengembangkan kemampuan berpikir kritis tidak boleh dilupakan juga mengenai pemahaman berpikir kritis itu sendiri. Desain pembelajaran yang mendukung pengembangan kemampuan berpikir kritis serta mengaplikasikan macam-macam berpikir yang memberi kontribusi berpikir kritis pada materi kuliah.

\section{DAFTAR PUSTAKA}

Birru, L. 2011. "Indeks Kerentanan Radikalisme" [Online] Tersedia: http://www. voanews.com/indonesian/news/Indeks-

Radikalisme-di-Indonesia [28 Desember 2011]

Center for Civic Education /CCE. 1998. We the People: Project Citizen. Calabasas:CCE.

Craddock dkk. 2007. "Teaching for Democracy: Assessing Project Citizen in Poland, South Africa", Research Report.

Formm, E. 1987. Memiliki dan Menjadi: tentang Dua Modus Eksistensi (Terj: F. Soesilohardo). Jakarta: LP3ES.

Langrehr, John. 2006. Thinking Skills. Edisi Pertama. Jakarta: PT.Gramedia.

Liliasari, 2010. "Pengembangan Berpikir Kritis Sebagai Karakter Bangsa Indonesia Melalui Pendidikan Sanis Berbasis ICT" dalam Suryadi, Karim et al. (2010) Potret Profesionalisme Guru dalam Membangun Karakter Bangsa: Pengalaman Indonesia Malaysia. Bandung: UPI.
Maksum, H. 2011. "Model Project Citizen Untuk Meningkatkan Kecakapan” Pendidikan Kewarganegaraan Pada Konsep Pengembangan Sikap Nasionalisme dalam Budimansyah, D. dan Bestari, P (2011) Aktualisasi Nilai-Nilai Pancasila dalam Membangun Karakter Warga Negara. Lab. PKn-UPI.

Moore, B.N. \& Parker, R. 2009. Critcal Thinking. New York: McGraw-Hill Co.Inc.

Muhadjir, N. 2000. Ilmu Pendidikan Dan Perubahan Sosial. Yogyakara: Rake Sarasin Indonesia.

Naisbit, J. 1990. Megatrends 2000. London: Sidgwick \& Jackson Ltd.

Sanusi, A. 1998. Pendidikan Alternatif: Menyentuh Asas Dasar Persoalan Pendidikan dan Kemasyarakatan. Bandung: Grafindo Media Pratama.

Sapriya. 2008. Pendidikan IPS. Bandung: Laboratorium PKn UPI Bandung.

Suabuana, C. 2010. "Pengembangan Pendidikan Nilai Bela Negara dalam Pendidikan Kewarganegaraan pada Perguruan Tinggi Melalui Model Pembelajaran Project Citizen" (Studi Analitik Tentang Pengembangan Nilai dalam rangka MKU Universitas Pendidikan Indonesia. Disertasi. Bandung. Program Studi Pendidikan Umum/ Nilai, Sekolah Pasca Sarjana Universitas Pendidikan Indonesia.

Sumardjono. 2001 "Teori Belajar" dalam Umbu Tagela (2001) Belajar di Era Informasi. Salatiga: Universitas Kristen Satya Wacana.

Wahab, A.A. 2008. Metode dan Model-Model Mengajar. Bandung: P.T. Alfabeta. 